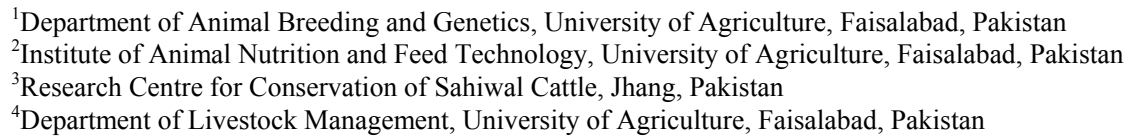

ZIA UR REHMAN ${ }^{1}$, M. SAJJAD KHAN ${ }^{1}$, SHAUKAT ALI BHATTI ${ }^{2}$, JAVED IQBAL ${ }^{3}$ and ARSHAD IQBAL $^{4}$

\title{
Factors affecting first lactation performance of Sahiwal cattle in Pakistan
}

\begin{abstract}
To study the environmental and genetic factors affecting productive and reproductive traits, data on 5,897 cows from five main recorded herds (for 1964-2004) of Sahiwal cattle in Pakistan were used. A general linear model was applied on the data. The 305-day milk yield, total milk yield, lactation length, age at first calving, dry period, calving interval and service period averaged 1,393 $\pm 12 \mathrm{~kg}, 1,429 \pm 11 \mathrm{~kg}, 235 \pm 2,1,390 \pm 4,244 \pm 3$, $464 \pm 3$ and $1,78 \pm 3$ days, respectively. The age at first calving was effected by herd, year and season of birth. The 305-day and total milk yields were affected by herd, year, season of calving, age at first calving, service period and lactation length while all other first lactation traits were affected by herd, year, season of calving and 305-day milk yield. Animal model heritability estimates for these traits were $0.11 \pm 0.029,0.11 \pm 0.028,0.09 \pm$ $0.027,0.02 \pm 0.019,0.05 \pm 0.019,0.12 \pm 0.027$ and $0.04 \pm 0.020$, respectively. Rate of decline in first lactation milk yield was 71 per year over the last 35 years with genetic trend close to zero. Lactation length and service period decreased and age at first calving increased by 2, 1 and 6 days per year, respectively. Herd differences for most of the traits were significant. Improved feeding and management may improve performance traits of Sahiwal cattle. Accurate recording of pedigrees and performance traits would help improve genetic parameters. Variation among animals suggested that genetic improvement in milk yield is possible in Sahiwal cattle.
\end{abstract}

Keywords: Sahiwal cattle, first lactation, performance traits, genetic trend, phenotypic trend

\section{Zusammenfassung}

Titel der Arbeit: Einflussfaktoren auf die Erstlaktationsleistung von Sahiwal-Rindern in Pakistan

Daten von 5.897 Sahiwal-Kühen aus fünf Betrieben in Pakistan der Jahre 1964 bis 2004 wurden hinsichtlich der Produktions- und Reproduktionsmerkmale unter dem Einfluss von Umwelt und Genetik bei Anwendung eines allgemeinen linearen Modells ausgewertet. Die Durchschnittswerte lagen für die Merkmale 305-Tage-Milchertrag bei $1.393 \pm 12 \mathrm{~kg}$, Gesamtmilchertrag $1.429 \pm 11 \mathrm{~kg}$, Laktationslänge $235 \pm 2$ Tage, Erstkalbealter $1.390 \pm 4$ Tage, Trockenperiode $244 \pm 3$ Tage, Zwischenkalbezeit $464 \pm 3$ Tage und Serviceperiode $178 \pm 3$ Tage. Das Erstkalbealter wurde durch Herde, Jahr und Geburtssaison beeinflusst. Der 305-Tage- und Gesamtmilchertrag wurde durch Herde, Jahr, Kalbesaison, Erstkalbealter, Dauer der Serviceperiode und Laktation beinflusst, während alle anderen Erstlaktationsmerkmale durch Herde, Jahr Kalbesaison und die 305-Tage-Milchleistung beeinflusst wurden. Die Heritabilitätsschätzwerte für die oben genannten Merkmale betrugen in der gleichen Merkmalsreihenfolge: $0,11 \pm 0,029 ; 0,11 \pm 0,028 ; 0,09 \pm 0,027 ; 0,02 \pm 0,019 ; 0,05 \pm 0,019 ; 0,12 \pm 0,027$ und $0,04 \pm 0,020$. Der Rückgang der Erstlaktationsleistung betrug in den zurückliegenden 35 Jahren jährlich 71 mit dem genetischen Trend nahe null. Die Verringerung der Länge für Laktationsdauer, Serviceperiode, und Erstkalbealter lagen bei zwei, einem bzw. sechs Tagen pro Jahr. Bei den meisten untersuchten Merkmalen waren die Unterschiede zwischen den Herden signifikant. Verbesserungen hinsichtlich Fütterung und Management ermöglichen Leistungsverbesserungen der Sahiwal-Rinder, ebenso wie eine genaue Abstammungs- und Leistungsdokumentation dazu beitragen wird, die genetischen Parameter zu verbessern. Die vorhandene genetische Variation bei dieser Population wird eine weitere Verbesserung der Milchleistung der SahiwalRinder ermöglichen. 


\section{Introduction}

Sahiwal cattle is dairy breed of Pakistan. It is considered as one of the best zebu milch breed in the tropics with higher disease resistance and heat tolerance properties. Many synthetics (such as Australian-Friesian-Sahiwal, Australian Milking Zebu, Frieswal, Jamaica Hope, Karan Swiss, Mafriwal, Mpwapwa and Taurindicus) have been developed from this breed for raising under tropical conditions. In its home tract, deterioration in its population number from 1.4 million (GOP, 1996) to 0.35 million (AHMAD et al., 2000) is ascribed to haphazard crossbreeding with Holstein for dairy purpose. Productivity has been either static or declining despite improved cattle management standards in commercial dairying. Genetic selection programme in the breed has almost been missing. Previous reports on the productive parameters of the breed vary considerably (Table 1 ).

The genetic correlations between first lactation traits play important role in deciding single vs. multiple trait selection strategy. Direction and extent of correlations among various traits both within and across breeds vary considerably. Genetic correlation between first lactation milk yield and age at first calving in an Indian study (CHOUDHARY et al., 2003) is reported as $-0.12 \pm 0.38$. However, MOHIUDDIN et al. (1991) and JAVED (1999) have reported this correlation as 0.44 and 0.60 , respectively. Genetic correlation between first lactation milk yield and lactation length has been reported from 0.23 to 0.83 (DAHLIN et al., 1998; JAVED, 1999 and CHOUDHARY et al., 2003).

Table 1

First lactation performance traits and their heritability $\left(\mathrm{h}^{2}\right)$ in Sahiwal cattle from some selected studies (Merkmale von Erstlaktationsleistungen [ELL] und deren Heritabilität $\left[\mathrm{h}^{2}\right]$ bei Sahiwal-Rindern ausgewählter Literaturquellen)

\begin{tabular}{lccr}
\hline $\begin{array}{l}\text { Performance trait*/ } \\
\text { heritability }\end{array}$ & \multicolumn{2}{c}{ Value } & References \\
\hline $305-\mathrm{d}$ LMY $(\mathrm{kg})$ & $1603 \pm 12.3$ & $1363 \pm 30.1$ & MOHIUDDIN et al. (1991), DAHLIN et al. (1998) \\
TLMY (kg) & $1314 \pm 23.7$ & $1395 \pm 9.9$ & TALBOTT (1994), DAHLIN et al. (1998) \\
LL (days) & $238 \pm 2.6$ & $232 \pm 1.3$ & TALBOTT (1994), DAHLIN et al. (1998) \\
AFC (days) & $1243 \pm 6.7$ & $1358 \pm 7.9$ & MOHIUDDIN et al. (1991), JAVED (1999) \\
DP (days) & $182 \pm 4.5$ & $228 \pm 11.7$ & AHMAD and AHMAD (1974), TALBOTT (1994) \\
CI (days) & $490 \pm 4.6$ & $465 \pm 124$ & AHMAD and AHMAD (1974), DAHLIN et al. (1998) \\
SP (days) & $154 \pm 5.3$ & $194 \pm 135$ & DESHPONDE et al. (1983), TALBOTT (1994) \\
$\mathrm{h}^{2}$ of 305-d LMY & $0.14 \pm 0.02$ & $0.22 \pm 0.04$ & DAHLIN et al. (1998), ILATSIA et al. (2007) \\
$\mathrm{h}^{2}$ of TLMY & $0.15 \pm 0.02$ & $0.01 \pm 0.02$ & DAHLIN et al. (1998), JAVED (1999) \\
$\mathrm{h}^{2}$ of LL & $0.17 \pm 0.03$ & $0.06 \pm 0.04$ & DAHLIN et al. (1998), JAVED (1999) \\
$\mathrm{h}^{2}$ of AFC & $0.12 \pm 0.02$ & $0.04 \pm 0.03$ & DAHLIN et al. (1998), JAVED (1999) \\
$\mathrm{h}^{2}$ of CI & $0.04 \pm 0.05$ & $0.07 \pm 0.02$ & MOHIUDDIN et al. (1991), DAHLIN et al. (1998) \\
$\mathrm{h}^{2}$ of DP & $0.04 \pm 0.05$ & $0.03 \pm 0.03$ & MOHIUDDIN et al. (1991), JAVED (1999) \\
$\mathrm{h}^{2}$ of SP & $0.04 \pm 0.03$ & $0.27 \pm 0.03$ & JAVED (1999), CHOUDHARY et al. (2003) \\
\hline *305-d LMY = 305-day lactation milk yield, TLMY total lactation milk yield, LL = lactation length, AFC = age at first calving, DP = dry \\
period, CI = calving interval, SP= service period
\end{tabular}

Efforts to develop Sahiwal breed have just been started in Pakistan. Establishment of Research Centre for Conservation of Sahiwal Cattle (RCCSC) is one of the steps taken in this direction. Genetic improvement programs require population estimates and trends to chalk out strategy for improvement in the breed. The present study was planned to evaluate inter-herd performance, environmental and genetic variation in first lactation performance traits of five main herds of Sahiwal cattle in Pakistan. 


\section{Materials and Methods}

Data on performance traits of Sahiwal Cattle from five main Governmental herds i.e. Livestock Experiment Station (LES) Allahdad, LES Bahadurnagar, LES Fazalpur, LES Jahangirabad and LES Khizerabad were utilized for this study. Lactation records of 5,897 Sahiwal cows sired by 300 males were available. Incomplete lactations for any recorded reason or ending with abortion or other anomaly were deleted. The number of records eliminated/edited was less than $4 \%$ for any trait under study (Table 2). Traits were analyzed under a fixed effect model having main effects of herd, year and season of birth/calving. Four seasons were defined as winter (December to February), spring (March to May), summer (June to August) and autumn (September to November). For 305-day and total lactation milk yield, lactation length, age at first calving and service period were fitted as covariables. For lactation length, age at first calving and service period were used as covariables. For calving interval, service period and dry period, the only variable was 305-day milk yield. These models were similar to CADY et al. (1983) and TALBOTT (1994). Two-way interactions of year of calvings/birth were not possible as data pertained to different years for various herds. Herd by season interaction was fitted in the preliminary analysis but removed afterwards because the interaction was not significant for most of the traits.

Table 2

Percent records removed after applying the edit criteria on first lactation traits (Prozentuale Abschlüsse bei Anwendung der Auswahlkriterien für ELL)

\begin{tabular}{|c|c|c|c|c|c|c|}
\hline \multirow{2}{*}{ Sr. No. } & \multirow{2}{*}{ Traits } & \multirow{2}{*}{ Total records } & \multirow{2}{*}{ Acceptable range } & \multicolumn{2}{|c|}{ Records removed } & \multirow{2}{*}{ Records used } \\
\hline & & & & No. & $\%$ & \\
\hline 1 & 305-day milk yield, kg & 5,872 & $>1 \mathrm{~kg} /$ day of LL & 170 & 2.9 & 5,702 \\
\hline 2 & Total milk yield, kg & 5,876 & $>1 \mathrm{~kg} /$ day of LL & 174 & 3.0 & 5,702 \\
\hline 3 & Lactation length, days & 5,660 & $>60$ & 165 & 2.9 & 5,495 \\
\hline 4 & Age at first calving, days & 5,897 & $<2,200$ days & 145 & 2.5 & 5,752 \\
\hline 5 & Dry period, days & 5,002 & $\geq 30$ to $\leq 730$ & 190 & 3.8 & 4,812 \\
\hline 6 & Calving interval, days & 4,996 & $\geq 300$ to $\leq 900$ & 169 & 3.4 & 4,827 \\
\hline 7 & Service period, days & 4,740 & $\geq 30$ to $\leq 600$ & 126 & 2.7 & 4,614 \\
\hline
\end{tabular}

$\mathrm{LL}=$ Lactation length

The $\mathrm{h}^{2}$ and genetic correlations of first lactation traits were estimated using Restricted Maximum Likelihood procedure outlined by (PATTERSON and THOMPSON, 1971) fitting an Individual Animal Model. Herd-year-season of calving (HYS) combinations was used as fixed effect except for age at first calving where it was season of birth. Proceeding and/or preceding seasons were grouped together to have minimum of five observations for any HYS. All the known relationships were accounted for. The model was:

$$
\mathrm{y}=\mathrm{Xb}+\mathrm{Za}+\mathrm{e}
$$

where $\mathrm{y}=$ vector of observations; $\mathrm{b}=$ vector of fixed effects (i.e. herd-year-season combinations); $\mathrm{a}=$ vector of random animal effects; $\mathrm{e}=$ vector of random residual effects; $\mathrm{X}$ and $\mathrm{Z}$ were incidence matrices relating records to fixed and random animal effects, respectively. The expected values of a and e were $E(a)=E(e)=0$. The variance-covariance structure assumed to be was $\mathrm{V}(\mathrm{a})=\mathrm{A} \sigma^{2} \mathrm{a} ; \mathrm{V}(\mathrm{e})=\mathrm{I} \sigma^{2} \mathrm{e}$, and $\operatorname{cov}(\mathrm{a}, \mathrm{e})=\operatorname{cov}(\mathrm{e}, \mathrm{a})=0 ; \operatorname{cov}(\mathrm{y}, \mathrm{a})=\mathrm{ZAI} \sigma^{2} \mathrm{a}$, where A was the numerator relationship matrix. 
For phenotypic and genetic correlations among some plausible combinations of traits, bivariate analysis was performed. The DFREML software (MEYER, 2000) was used to estimate genetic parameters and estimated breeding values (EBVs). The EBVs were then fitted in a fixed effect model having year of birth to get least squares solutions for plotting genetic trends. Fixed effect models were run using Statistical Package for Social Scientist (SPSS, 2004).

\section{Results}

305-day milk yield

First lactation 305-day milk yield varied widely among different herds (Table 3 ). The production was highest at LES Allahdad and the lowest at LES Fazilpur. The first lactation 305-day milk yield of cows calving during different years showed a wide variation (Figure 1) but generally declined over the years. Phenotypic trend was $-3.7 \mathrm{~kg} /$ year from 1966 to 2003 . Genetic trend was close to zero (Figure 2).

\section{Total milk yield}

The average lactation yield varied under different herd management conditions during different years and seasons (Table 3). The best lactation yield was observed in LES Allahdad whereas minimum at LES Fazilpur herd. The first lactation milk yield of cows calving in different years showed a wide variation with gradually decreasing trend over the years (Figure 1). Autumn calvers had highest yield and seasonal pattern was similar to 305-day yield (Figure 3). The $\mathrm{h}^{2}$ estimate for first lactation total milk yield was similar to 305 -day milk yield (Table 4 ). The genetic trend was close to zero (Figure 2).

\section{Lactation length}

The first lactation length averaged $235 \pm 2.2$ days (Table 3). Cows at LES Bahadurnagar had longest lactation length while it was minimum in cows at LES Fazilpur. Phenotypic trend was negative. Lactation length decreased by 2 days per year over the last 38 years (Figure 1). Spring calvers had higher lactation length than the cows calving in other seasons (Figure 3). No specific genetic trend was observed for first lactation length (Figure 2).

\section{Age at first calving}

The overall age at first calving was $1390 \pm 3.9$ days with a range of 1,327 to 1,510 days among herds (Table 3). Cows at LES Bahadurnagar calved at the youngest age $(1,327 \pm 4.6$ days). Overall phenotypic trend in the trait was positive $(+5.6$ days/year $)$ with wide variation among herds (-8.4 to 21.9 days/year) (Figure 1$)$. The $h^{2}$ estimate for age at first calving was close to zero $(0.02 \pm 0.019)$. The genetic correlation of age at first calving with first lactation 305-day milk yield, first lactation total milk yield, first lactation length, first calving period, first dry period and first service period were $0.72,0.44,0.71,0.72,0.31$ and 0.64 , respectively.

\section{Dry period}

The first dry period was $244 \pm 2.8$ days (Table 3). Herd average varied between $198 \pm 3.4$ days (LES Bahadurnagar) and $277 \pm 4.8$ days (LES Khizerabad). Dry period varied in different herds over years of calving. First lactation 305-day milk yield was found as 
important covariable. Season of calving had no effect on first dry period. The dry period in all herds was too long and increasing $(+1.31$ days/year) over years (Figure 1). The dry period averaged 248, 246, 243 and 238 days for summer, autumn, spring and winter seasons, respectively. The $\mathrm{h}^{2}$ estimate for first dry period was $0.05 \pm 0.02$ (Table 4). The phenotypic, genetic and residual correlation between age at first calving and first dry period were $0.19,0.31$ and -0.23 , respectively while with lactation milk yield, corresponding figures were $0.27,0.53$ and 0.17 , respectively (Table 5). The estimated breeding values for first dry period were -48 to 35 days in sires and -40 to 34 days in cows (Table 6). The genetic trend in dry period was close to zero (Figure 2).

The 305-day milk yield was maximum in cows calving during autumn and minimum in summer season (Figure 3). No specific genetic trend was observed for 305-day milk yield during the period under study (Figure 1).

\section{Calving interval}

Calving interval varied across different herd during different years. The lowest interval was observed at LES Allahdad and longest at LES Khizerabad. The cows calving in different years showed wide variation in first calving interval (Figure 1). Of the covariates, first lactation 305-day milk yield also affected the trait significantly $(\mathrm{p}>0.01)$. High producing cows had longer interval than low producers. The additive genetic merit of cows calving in different years did not show any improvement (Figure 2).

\section{Service period}

First service period averaged $178 \pm 3$ days (Table 3). It was minimum at LES Allahdad. Service period increased (1days/year) over the years (Figure 1). The shortest service period was recorded in winter calvers while the summer calvers took one month longer to rebreed. Heifers calving in spring and autumn seasons took $178 \pm 3.5$ and $179 \pm 5.1$ days, respectively to rebreed (Figure 3 ). The genetic trend was also close to zero for first service period during the years under study (Figure 2).

Table 3

Means for first lactation traits by herds and seasons*

(ELL in Bezug auf Herden und Jahreszeiten)

\begin{tabular}{lrccc}
\hline Trait & $\mathrm{N}$ & $\begin{array}{c}\text { 305-day milk yield }(\mathrm{kg}) \\
\text { Mean } \pm \mathrm{SE}\end{array}$ & $\begin{array}{c}\text { Total milk yield }(\mathrm{kg}) \\
\text { Mean } \pm \mathrm{SE}\end{array}$ & $\begin{array}{c}\text { Lactation length (days) } \\
\text { Mean } \pm \mathrm{SE}\end{array}$ \\
\hline Herds & & & & $255 \pm 3.5$ \\
$\quad$ LES Allahdad & 557 & $1,630 \pm 18.8$ & $1,635 \pm 18.3$ & $268 \pm 2.2$ \\
LES Bahadunagar & 1,836 & $1,300 \pm 11.8$ & $1,355 \pm 11.5$ & $192 \pm 7.2$ \\
LES Fazilpur & 107 & $1,153 \pm 39.0$ & $1,224 \pm 37.9$ & $226 \pm 2.3$ \\
LES Jehangirabad & 1,324 & $1,401 \pm 12.6$ & $1,431 \pm 12.3$ & $235 \pm 3.1$ \\
LES Khizerabad & 753 & $1,481 \pm 16.7$ & $1,500 \pm 16.3$ & $235 \pm 2.5$ \\
Season & & & & $243 \pm 2.6$ \\
$\quad$ Winter & 1,860 & $1,417 \pm 13.2$ & $1,452 \pm 12.9$ & $239 \pm 3.2$ \\
Spring & 1,467 & $1,354 \pm 13.7$ & $1,392 \pm 13.3$ & $224 \pm 3.7$ \\
Summer & 722 & $1,341 \pm 17.3$ & $1,380 \pm 16.8$ & $235 \pm 2.2$ \\
$\quad$ Autumn & 528 & $1,460 \pm 19.7$ & $1,493 \pm 19.2$ & $1,429 \pm 11.4$ \\
Overall & 4,577 & $1,393 \pm 11.7$ & & \\
\hline
\end{tabular}


Table 3 (continuation)

\begin{tabular}{|c|c|c|c|c|c|c|c|c|}
\hline \multirow[t]{2}{*}{ Trait } & \multicolumn{2}{|c|}{$\begin{array}{c}\text { Age at first calving, } \\
\text { days }\end{array}$} & \multicolumn{2}{|c|}{$\begin{array}{l}\text { Dry period, } \\
\text { days }\end{array}$} & \multicolumn{2}{|c|}{$\begin{array}{l}\text { Calving interval, } \\
\text { days }\end{array}$} & \multicolumn{2}{|c|}{$\begin{array}{c}\text { Service period, } \\
\text { days }\end{array}$} \\
\hline & $\mathrm{N}$ & Mean $\pm \mathrm{SE}$ & $\mathrm{N}$ & Mean \pm SE & $\mathrm{N}$ & Mean \pm SE & $\mathrm{N}$ & Mean $\pm \mathrm{SE}$ \\
\hline \multicolumn{9}{|l|}{ Herds } \\
\hline LES Allahdad & 644 & $1,368 \pm 8.9$ & 533 & $193 \pm 5.9$ & 548 & $413 \pm 5.5$ & 552 & $131 \pm 5.5$ \\
\hline LES Bahadunagar & 2,404 & $1,327 \pm 4.6$ & 1,834 & $198 \pm 3.4$ & 1,835 & $460 \pm 3.1$ & 1,828 & $177 \pm 3.2$ \\
\hline LES Fazilpur & 280 & $1,510 \pm 13.0$ & 232 & $323 \pm 8.4$ & 283 & $475 \pm 7.4$ & 139 & $188 \pm 10.4$ \\
\hline LES Jehangirabad & 1,511 & $1,380 \pm 5.6$ & 1,370 & $228 \pm 3.7$ & 1,362 & $459 \pm 3.4$ & 1,345 & $169 \pm 3.5$ \\
\hline LES Khize & 913 & $1,367 \pm 7.5$ & 775 & $277 \pm 4.9$ & 762 & $514 \pm 4.7$ & 750 & $227 \pm 4.8$ \\
\hline \multicolumn{9}{|l|}{ Season } \\
\hline Winter & 2,131 & $1,398 \pm 5.2$ & 1,969 & $248 \pm 3.3$ & 1,998 & $464 \pm 3.0$ & 644 & $166 \pm 5.2$ \\
\hline Spring & 1,547 & $1,392 \pm 5.9$ & 1,488 & $243 \pm 3.7$ & 1,511 & $470 \pm 3.4$ & 2,090 & $178 \pm 3.5$ \\
\hline Summer & 1,034 & $1,385 \pm 7.1$ & 729 & $238 \pm 4.9$ & 727 & $468 \pm 4.7$ & 1,246 & $191 \pm 4.0$ \\
\hline Autumn & 1,040 & $1,385 \pm 7.2$ & 558 & $246 \pm 5.5$ & 554 & $455 \pm 5.2$ & 634 & $179 \pm 5.1$ \\
\hline Overall & 5,752 & $1,390 \pm 3.9$ & 4,744 & $244 \pm 2.8$ & 4,790 & $464 \pm 2.5$ & 4,614 & $178 \pm 3.1$ \\
\hline
\end{tabular}

* Season of calving for all traits except for age at first calving where it was season of birth. $\mathrm{N}$ in the nearest left column is relevant.

Table 4

Additive genetic variance and heritability $\left(\mathrm{h}^{2}\right)$ estimates for first lactation traits

(Additiv genetische Varianz und Heritabilitätsschätzwerte $\left[\mathrm{h}^{2}\right]$ für Erstlaktationsmerkmale [ELM])

\begin{tabular}{lccrr}
\hline Traits & $\mathrm{N}$ & $\begin{array}{c}\text { Additive genetic } \\
\text { variance }\end{array}$ & Phenotypic variance & $\mathrm{h}^{2} \pm \mathrm{SE}$ \\
\hline 305-day milk yield & 5,702 & $32,925.3$ & $288,231.6$ & $0.11 \pm 0.029$ \\
Total milk yield & 5,702 & $37,934.5$ & $332,458.1$ & $0.11 \pm 0.028$ \\
Lactation length & 5,495 & 448.4 & $5,185.1$ & $0.09 \pm 0.027$ \\
Age at first calving & 5,752 & 601.4 & $33,602.8$ & $0.02 \pm 0.019$ \\
Dry period & 4,812 & 742.2 & $14,930.3$ & $0.05 \pm 0.019$ \\
Calving interval & 4,827 & $1,712.0$ & $14,104.0$ & $0.12 \pm 0.027$ \\
Service period & 4,614 & 556.6 & $12,572.9$ & $0.04 \pm 0.020$ \\
\hline
\end{tabular}

Table 5

Genetic, phenotypic and environmental correlations among various first lactation traits (Genetische, phänotypische und Umwelt-Korrelationen verschiedener ELM)

\begin{tabular}{lccr}
\hline Traits & $\begin{array}{c}\text { Phenotypic } \\
\text { correlation }\end{array}$ & $\begin{array}{c}\text { Genetic correlation } \\
\text { Lactation milk yield and lactation length }\end{array}$ & $\begin{array}{c}\text { Environmental } \\
\text { correlation }\end{array}$ \\
\hline Lactation milk yield and dry period & 0.30 & $0.40 \pm 0.002$ & 0.32 \\
Age at first calving and 305-day milk yield & 0.27 & $0.53 \pm 0.000$ & 0.17 \\
Lactation length and 305-day milk yield & 0.45 & $0.72 \pm 0.031$ & -0.20 \\
Age at first calving and total milk yield & 0.22 & $0.40 \pm 0.002$ & 0.49 \\
Age at first calving and lactation length & 0.72 & $0.44 \pm 0.004$ & -0.37 \\
Age at first calving and service period & 0.55 & $0.64 \pm 0.001$ & 0.73 \\
Age at first calving and calving interval & 0.62 & $0.72 \pm 0.001$ & 0.41 \\
Age at first calving and dry period & 0.20 & $0.31 \pm 0.040$ & 0.41 \\
\hline
\end{tabular}

Table 6

Average estimated breeding values (EBVs) for sires and cows

(Geschätzte Durchschnitts-Zuchtwerte für Bullen und Kühe)

\begin{tabular}{lcc}
\hline Traits & EBVs for Sires & EBVs for Cows \\
\hline 305-day milk yield (kg) & -88 to 179 & -125 to 181 \\
Total milk yield (kg) & -82 to 148 & -110 to 160 \\
Lactation length (days) & -26 to 40 & -27 to 41 \\
Age at first calving (days) & -19 to 22 & -21 to 22 \\
Dry period (days) & -48 to 35 & -40 to 34 \\
Calving interval (days) & -66 to 63 & -69 to 60 \\
Service period (days) & -24 to 47 & -27 to 33 \\
\hline
\end{tabular}


305-day milk yield

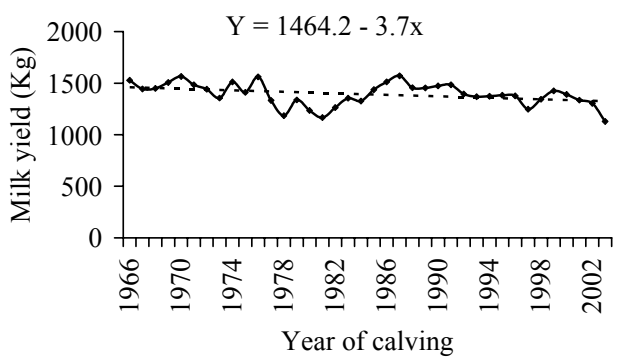

Lactation length

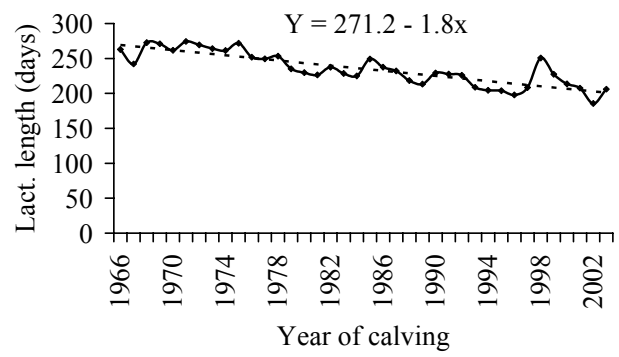

Age at first calving



Total lactation milk yield



Dry period

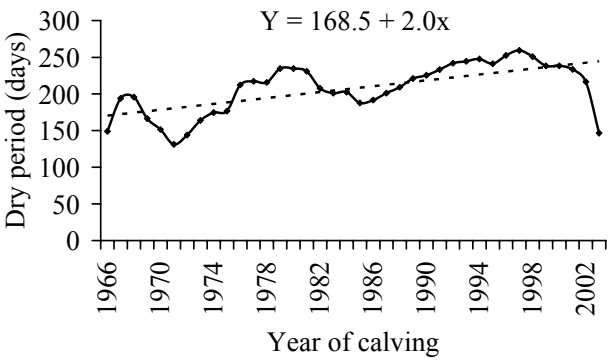

Calving interval

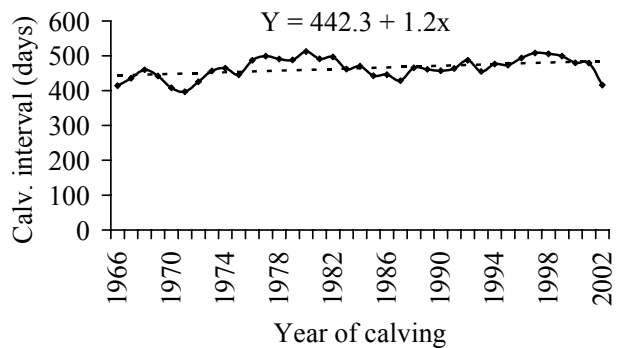

Service period



Fig. 1: Phenotypic trends in first lactation performance traits of Sahiwal (Phänotypische Trends der ELL bei Sahiwal-Kühen) 
305-day milk yield

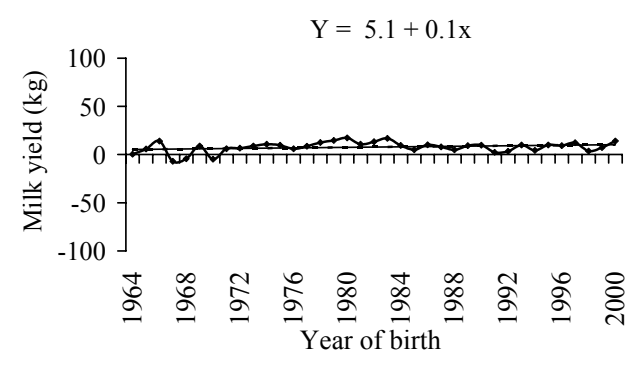

Lactation length

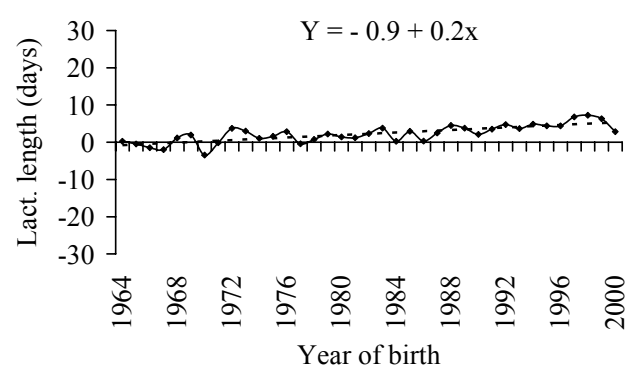

Age at first calving

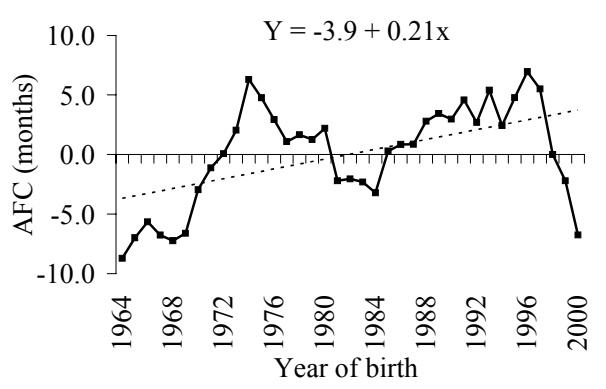

Total lactation milk yield

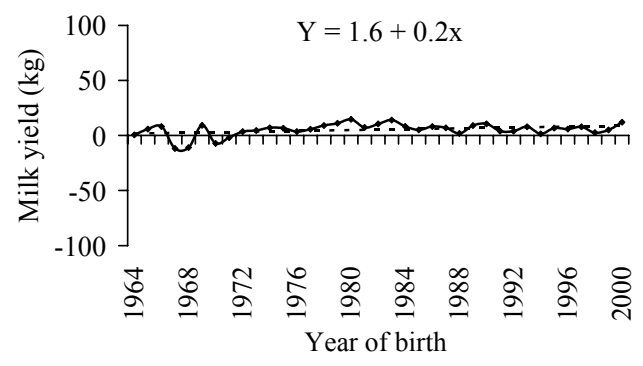

Dry period

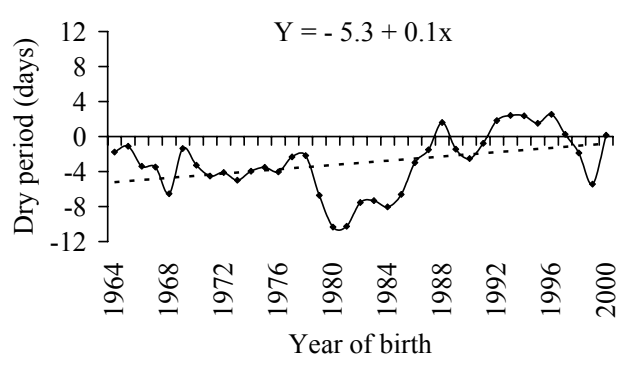

Calving interval



Service period



Fig. 2: Genetic trends in first lactation performance traits of Sahiwal (Genetische Trends der ELL bei SahiwalKühen) 
305-day milk yield

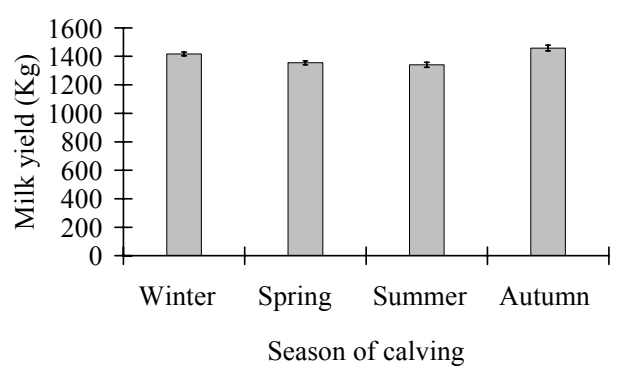

Lactation length



Total lactation milk yield

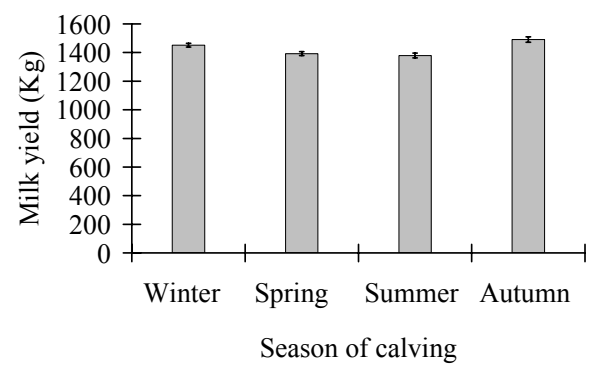

Service period



Fig. 3: Seasonal variation in first lactation performance traits of Sahiwal (Saisonale Variation bei ELL von Sahiwal-Kühen)

\section{Discussion}

The findings of the present study are in line with earlier reports on Sahiwal cattle in Pakistan (DAHLIN et al., 1998). A higher first lactation 305-day milk yield (2,083 \pm 33 $\mathrm{kg}$ ) based on 580 observations have been reported by BHATNAGAR et al. (1983) for Indian Sahiwal. REGE et al. (1992) reported an average of 1,145 $\mathrm{kg}$ for the Kenyan Sahiwal herd. Year and season effects on 305-day yield have previously been documented (DAHLIN et al., 1998; JAVED, 1999). Winter calvers produce more milk because they peak and persist better than the summer calvers (KHAN, 1997) because of more fodder availability during spring season. Difference of $477 \mathrm{~kg}$ between highest and lowest herd in the present study is probably due to differences in availability of feed resources and managemental practices. Thus better management and feeding results in more milk than otherwise.

The $\mathrm{h}^{2}$ estimates reported in the present study are in the range of previous reports. Estimates have been reported between 0.01 to 0.18 for some of the herds in Pakistan (DAHLIN et al., 1998; JAVED, 1999; AHMAD et al., 2001). Higher estimate (0.25) has been reported for Sahiwal in India (BHATNAGAR et al., 1983). Genetic correlation between 305-day milk yield and age at first calving calculated in the present study was similar to earlier reports on Sahiwal (GANDHI and GURNANI, 1988; DAHLIN et al., 1998) and other breeds under tropical conditions (GADER et al., 2007). Adequate genetic variation in 305-day milk yield (DAHLIN et al., 1998) 
suggested good scope for genetic improvement in the trait. Genetic correlation between first lactation 305-day milk yield and lactation length was 0.41 which was not the same as $0.83 \pm 0.04$ estimated by DAHLIN et al. (1998). Thus the suggestion that genetic correlation between the traits is close to unity and milk yield may not to be recorded, is not supported by the present study.

Present findings regarding lactation length are similar to DAHLIN et al. (1998) while Ahmad and Ahmad (1974) reported higher lactation length $(306.58 \pm 2.67$ days) for Sahiwal cows in one of the Sahiwal herds in Pakistan. Present $h^{2}$ estimate is in close conformity with the findings of JAVED (1999) $(0.062 \pm 0.039)$ and REDDY and NAGARCENKAR (1989) who reported the $\mathrm{h}^{2}$ estimate for $1^{\text {st }}$ lactation length between 0 and $0.19 \pm 0.20$ in five Sahiwal herds.

The age at first calving obtained in present investigation is quiet high as compared to previously reported (1,242 to 1,345 days) in Pakistani Sahiwals (AHMAD et al., 1992; MOHIUDDIN et al., 1994; TALBOTT, 1994; KHAN et al., 1999). Smaller age at first calving (1,112 days) has been reported for Sahiwal herd in Kenya (REGE et al., 1992). Weak genetic control of the trait suggests improvement in the feeding and management may reduce the age at first calving. Some of the previous reports (MOHIUDDIN et al., 1994; JAVED, 1999; KHATTAB et al., 2005) estimated genetic control close to zero for Sahiwal in Pakistan. However, some Indian studies (TOMAR et al., 1974) reported $h^{2}$ in the medium to high range. Genetic correlation between age at first calving and other traits have high variability as reported by various workers (DAHLIN et al., 1998; JAVED, 1999). Increasing age at first calving at the rate of 22 days per year (LES Fazilpur) is reflective of deteriorating feeding and managemental practices in the replacement herd.

The longer dry period found in the present study indicated poor reproductive management. When lactation length decreased over the years and so did the calving interval, dry period was likely to increase. Previously, Ahmad and Ahmad (1974) reported lower 1 st dry period $(182 \pm 4.49$ days). The low additive genetic control $\left(\mathrm{h}^{2}=0.03 \pm 0.03\right)$ reported earlier (JAVED, 1999; KÖNIG et al., 2005) and in the present study pointed out to improvement in management. The generally accepted standard dry period of 60 days for improved breeds was far away in the Sahiwal herds under study.

AHMAD and AHMAD (1974) reported calving interval of $490.21 \pm 4.65$ days in Sahiwals. Contrary to present study, significant effect of season of calving on the first calving interval has been documented (PYNE and DATTAGUPTA, 1994).

First calving interval was lowly heritable in the present study which is similar to earlier reports on Sahiwal breed (CHAND and NARAIN, 1984; DESHPANDE et al., 1983). Its genetic correlation with age at first calving was favourable because selecting for lower age at calving would also improve calving interval favourably. Longer calving interval with increasing trend over the years puts a threat to the breed's economic viability. The situation will worsen if the current status persists. Improvement in feeding and reproductive management may help in reducing the calving interval. The low estimates of additive genetic control on the trait also indicated need for more detailed investigations into the environmental sources of variation masking genetic variation.

Reduction of first service period for reduction of calving interval is required for economical milk production. The longer service period does influence the milk yield 
and vice versa as reported by TALBOTT (1994) and DAHLIN et al. (1998). Optimum milk production in Sahiwal requires that cows calving in summer and autumn be given due attention to reduce service period. Cows calving in the most frequent calving season (winter) had the shortest service period (166 \pm 5.2 days) and would need special attention with respect to feeding and reproduction as if they do not breed within 90 days are likely to have longer calving interval.

The lower $h^{2}$ estimates of service period were similar to earlier reports (DESHPANDE et al., 1983; RATHI et al.,1992; JAVED, 1999). The genetic correlation between age at first calving and first service period in the present investigation are similar to the study of BARWE et al. (1996) who reported the genetic correlation of 0.50 in Gir cattle. Genetic correlation of 0.54 suggests that improvement in age at first calving will reduce the service period.

Performance of Sahiwal cattle for first parity traits may be similar to the earlier reports in the literature but deterioration in phenotypic and genetic ability in most of the economical traits is alarming. Not just culling on performance would be helpful, present recording and selection protocols need to be revised. Selection of AI bulls on the basis of highest lactation yield of their dams might also need to be looked into. Weight is generally a neglected trait at most of the government farms. It can help to further pin point deficiencies in the system. Genetic control of milk yield was estimated to be lower than some of the previous studies on Sahiwal and could be improved through eliminating factors which caused high variation in temporary environment. Cows calving in most frequent calving season (winter) have higher lactation yield, long lactation length and shortest service period. Therefore, to improve productivity of Sahiwal cows for first lactation traits, first 90 days of cows if get improved management, situation might improve. Some of the differences observed for seasons of calving may be due to grouping of months to account for seasonal temperature and humidity as compared to grouping on calving pattern. Herd differences in age at first calving also indicated lack of feeding management in female young calves. Recently started efforts to develop the breed need to focus on widening the genetic base by involving as many as large herd with the farmers, as possible and selection of young bulls for artificial insemination. There is a lot of variation and scope for improvement in the Sahiwal breed.

\section{Acknowledgements}

Study was supported by Agriculture Linkage Program (ALP) of Pakistan Agriculture Research Council (PARC) through a project "Development of milk recording and genetic evaluation models in Sahiwal cattle" being executed at the Department of Animal Breeding and Genetics, University of Agriculture, Faisalabad (Pakistan).

\section{References}

AHMAD, Z.; PERVEEN, R.; MOHIUDDIN, G.; KHAN, M.A.; AKHTAR, P.:

Genetic and phenotypic parameters of some reproductive traits in Sahiwal cows. J. Anim. Plant Sci. 2 (1992), 11-14

AHMAD, M.; BUKHARI, A.; AWAN, F.; SAEED, M.N.:

Punjab Livestock Census. Vol. 1. Livestock and Dairy Development Department Punjab, Lahore, Pakistan (2000) 
AHMAD, M.; VAN DER WERF, J.H.J.; JAVED, K.:

Heritability estimates for some economic traits in Sahiwal and crossbred dairy cattle. J. Anim. Plant Sci. 11 (2001), 143-146

AHMAD, Z.; AHMAD, M.D.:

Effect of age at first calving on length of first lactation, dry period and calving interval in Sahiwal cows. Agric. Pak. 25 (1974), 45-48

BARWE, V.K.; DHINGRA, M.M.; TOMAR, S.S.:

Factors affecting age at first calving and its genetic relationship with other reproductive traits in Gir cows. Indian J. Dairy Sci. 49 (1996), 100-104

BHATNAGAR, D.S.; TANEJA, V.K.; BASU, S.B.; MURTHY, K.M.K.:

Genetic parameters for some economic traits in Sahiwal cattle. Indian J. Dairy Sci. 36 (1983), 402-406

CADY, R.A.; SHAH, S.K.; SCHERMERHORN, E.C.; MCDOWELL, R.E.: Factors affecting performance of Nili-Ravi Buffaloes in Pakistan. J. Dairy Sci. 66 (1983), 578-586

CHAND, L.; NARAIN, P.:

Genetic parameters of lactation performance index in Sahiwal cattle. Indian J. Anim. Sci. 54 (1984), 204-205

CHOUDHARY, V.; KOTHEKAR, M.D.; RAHEJA, K.L.; KASTURIWALE, N.N.; KHIRE, D.W.; KUMAR, P.: Genetic evaluation of first lactation traits in Sahiwal cattle using Restricted Maximum Likelihood Technique. Asian-Aust. J. Anim. Sci. 16 (2003), 639-643

DAHLIN, A.; KHAN, U.N.; ZAFAR, A.H.; SALEEM, M.; CHAUDHRY, M.A.; PHILIPSSON, J.:

Genetic and environmental causes of variation in milk production traits of Sahiwal cattle in Pakistan. Anim. Sci. 66 (1998), 307-318

DESHPANDE, K.S.; INGOLE, G. K.; SAKHARE, P.G.:

Factors affecting service period and calving interval in Friesian X Sahiwal crossbreds. Indian J. Anim. Sci. 58 (1983), 986-987

GADER, A.Z.A.; AHMAD, M.A.; MUSA, L.A.; PETERS, K.J.:

Milk yield and reproductive performance of Friesian cows under Sudan tropical conditions. Arch. Tierz. 50 (2007), 155-164

GANDHI, R.S.; GURNANI, M.:

Association amongst different productive and reproductive traits in Sahiwal cattle. Asian J. Dairy Res. 7 (1988), 171-174

GOP (GOVERNMENT OF PAKISTAN):

Livestock Census. All Pakistan Report. Agricultural Census organization, Statistics Division, Lahore (1996)

ILATSIA, E.D.; MUASYA, T.K.; MUHUYI, W.B.; KAHI, A.K.:

Genetic and phenotypic parameters and annual trends for milk production and fertility traits of the Sahiwal cattle in semi arid Kenya. Trop. Anim. Health Prod. 39 (2007), 37-48

JAVED, K.:

Genetic and phenotypic aspects of some performance traits in a purebred herd of Sahiwal cattle in Pakistan. Ph.D. Thesis, University of Agriculture Faisalabad, Pakistan (1999)

KHAN, M.S.:

Lactation curve of Sahiwal cattle. Pak. Vet. J. 17 (1997), 107-110

KHAN, U.N.; DAHLIN, A.; ZAFAR, A.H.; SALEEM, M.; CHAUDHRY, M.A.; PHILIPSSON, J.:

Sahiwal cattle in Pakistan: genetic and environmental causes of variation in body weight and reproduction and their relationship to milk production. Anim. Sci. 68 (1999), 97-108

KHATTAB, A.S.; ATIL, H.; BADAWY, L.:

Variances of direct and maternal genetic effects for milk yield and age at first calving in a herd of Friesian cattle in Egypt. Arch. Tierz. 48 (2005), 24-31

KÖNIG, S.; CHONGKASIKIT, N.; LANGHOLZ, H.:

Estimation of variance components for production and fertility traits in Northern Thai dairy cattle to define optimum breeding strategies. Arch. Tierz. 48 (2005), 233-246

MEYER, K.:

User's notes of DFREML set of computer programmes, version $3.1 \beta(2000)$

MOHIUDDIN, G.; YAQOOB, M.; NAWAZ, H.; AKHTAR, P.:

Inheritance of breeding efficiency and its relationship with age at first calving and first lactation milk yield in Sahiwal cattle. Pak. Vet. J. 14 (1991), 238-241

PATTERSON, H.D.; THOMPSON, R.:

Recovery of inter-block information when block sizes are unequal. Biomet. 58 (1971), 545-554 
PYNE, K.; DATTAGUPTA, R.:

Influence of season of calving on some economic traits in Jersey-Hariana crossbred cows in west Bengal. Indian Vet. J. 71 (1994), 231-233

RATHI, R.C.; SHARMA, R.; SINGH, V.; TRIPATHI, S.C.:

Genetic studies of reproductive traits in Sahiwal and its crossbreds. Int. J. Anim. Sci. 7 (1992), 93-95

REDDY, K. M.; NAGARCENKAR, R.:

Inheritance of first lactation traits in Sahiwal cattle. Indian J. Dairy Sci. 42 (1989), 382-383

REGE, J.E.O.; LOMOLE, M.A.; WAKHUNGU, J.W.:

An evaluation of a long-term breeding programme in a closed Sahiwal herd in Kenya. I. Effect of nongenetic factors on performance and genetic parameter estimates. J. Anim. Breed. Genet. 109 (1992), 364-373

SPSS:

Statistical Package for Social Sciences. Release 10.0.1 version. SPSS Inc. (2004)

TALBOTT, C.W.:

Potential to increase milk yield efficiency in tropical countries. Ph.D. Thesis, North California State Univ. Raleigh, USA (1994)

TOMAR, S.P.; SINGH, S.B.; RAI, B.P.; SHARMA, R.C.:

Genetic aspects of age at first calving and first lactation milk yield in Sahiwal cows. Indian Vet. J. 51 (1974), 245-248



